\title{
A CLASSIFICATION OF THE PSOCIDÆ
}

\author{
BY NATHAN BANKS \\ Museum of Comparative Zoology, \\ Cambridge, Mass.
}

For a long time it has been customary to divide the Psocidæ into two sections according to the number of joints in the tarsi, two or three. By this division certain genera (as Myopsocus and Mesopsocus) were placed with the Trimera, although their venation is practically the same as the typical genus, Psocus, with two-jointed tarsi. The venational peculiarity of these higher Psocidæ is in a certain form of stigma, as well as in the modification of the cubital fork to form what is called an "areola postica." The three-jointed tarsi is a primitive character, and should not have as much weight as a special development within the family. I have prepared the following table placing emphasis on this areola postica and the stigma. The number of tarsal joints I would consider as of not more than tribal value; hardly, if any, more valuable than the forked media in hind wing, also a primitive character.

The use of the number of antennal joints as a primary character is open to the same objections as that of the number of tarsal joints, with the added force that the groups overlap. The use of the character of anal and axillary vein in forewing being separate throughout or united at the tip transfers the Amphientominæ from the other scaly-winged species to the group of the true Psocidæ. While there is no doubt that Amphientomum approximates nearer than does any other scaly-winged form, to the true Psocidæ, yet the venation (except for this condition in the anal region) is so close to that of other scaly-winged forms, and so different from the true Psocidæ that it cannot be neglected with reason. Moreover the head of Amphientomum, as well as 
pronotum, is much more like that of Perientomum than of any of the true Psocidæ. The presence of scales is also a character of some value. Moreover the genus Psyllipsocus has the anal and axillary ending together, and this surely is not allied to the true Psocidæ.

Perhaps it would be better to consider the scaly-winged species to belong to two families rather than two subfamilies, but I think that the differences between them are not as important as between them and the true Psocidæ. Indeed I think that they form a tendency to run into the Psyllipsocidæ. Embidopsocus I have united with Archipsocus in one family, although it might be better to put each in a family; both are primitive as to the pronotum and some other characters, but have a reduced rather than primitive venation. It is among the scaly-winged species that we find the more primitive forms. On the one side there has been a reduction of pronotum and specialization in venation to the true Psocids, and on the other side a reduction in wing-characters toward the Atropidæ.

The old family Psocidæ I would consder as a superfamily, Psocoidea with the following families, subfamilies and tribes as in the table.

Zorotypus I would also include in the order Corrodentia as the superfamily Zorotypoidea.

I would place Hemipsocus in the Creciliin ; the venation (outside of the cross-vein) is more that of Crcilius than of Psocus.

Certain Epipsocus show that the separation between the Crciliinæ and Psocinæ is not of great moment, and perhaps it would be better to reduce these groups to tribes.

Vulturops Towns. will go in the family Psoquillidx. Heteropsocus is the same as Psoquilla, but the species is distinct. Psocinella and Psocathropos differ in length of hind femora. Notiopsocus and Allopsocus go in the Peripsocini. Rhyopsocus goes in the Psylloneurinæ.

1. No wings, or only scale-like wings without definite venation; no ocelli; tarsi three-jointed, antennæ 15 or more jointed; pronotum visible above Atropidx Wings with definite venation present 
2. Forewings with a definite stigma; cubital fork developed into an "areola postica" with a narrowed base, or else no cubital fork; the first fork of median vein never reaches back to near base of stigma; anal and axillary end in one point; wings not scaled; 3 ocelli; pronotum rarely distinct from above; antennæ 13 jointed; tarsi two- or three-jointed Psocidx No distinct stigma, if one apparent then wing scaled and the first fork of median vein reaches back nearly as far as base of apparent stigma; no areola postica with narrowed base, the cubital fork is a normal fork, usually long; anal and axillary often separate at tip; ocelli present or absent, antennæ usually more than 13 jointed; tarsi three-jointed; pronotum often distinct from above

3. Wings clothed with scales; both wings present, veins reach to margin Wings not with scales

Perientomidæ

4. No hind wings, or extremely minute; venation reduced, some very long bristles; no ocelli; anal and axillary separate, meso- and metathorax separated, pronotum visible from above Hind wings of fair size; usually ocelli

Psoquillidæx

5. Venation complete, that is all main veins reach margin, two or three branches end in costa, pronotum not particularly prominent from above; antennæ 20 or more joints

Empheridx Venation reduced, some veins not reaching tip; pronotum very prominent from above; meso-and metanotum separate; antennæ 13 to 15 jointed, eyes not hairy

Embidopsocidæ

\section{TABles to Subfamilies and TRIBES}

\section{Atropidæ}

Claws without tooth; meso- and metanotum separated; antennæ 22 or more joints, wings absent or scale-like 
Claws with a tooth; meso- and metanotum united, antennæ 15 jointed; no wings

\section{Psoquillidæ}

The few genera do not readily separate into groups.

\section{Embidopsocidæ}

Two longitudinal veins unbranched

Embidopsocinæ

Two longitudinal veins branched and connected Archipsocinæ

Empheridæ

Hind wings with median forked

Hind wings with median simple

Empherinæ

Psylloneurinæ

\section{Perientomidx}

Anal and axillary end in one point antennæ 13 jointed or a few more; no closed cell near middle of fore wing; media of hind wing simple

Amphientominæ

Anal and axillary separate at tip; usually a small closed cell near middle of fore-wings; median of hind wings forked; antennæ 20 or more jointed.

Perientominæ

\section{Psocidx}

1. In hind wing median vein forked; wings sometimes partly netted. Calopsocinæ Median vein of hind wings simple...

2. Areola postica (sometimes absent) free, or if connected to media then its end is as far out as end of stigma

Cæcilinæ

Areola postica present and either united at top to media or connected by a cross-vein, and usually ending before end of stigma 
3. Radius (near base of radial fork) connected a second time to the media, thus forming two closed cells near middle of wing Thyrosophorinæ Radius connected but once to media, and thus forming but one closed cell near middle of wing.....Psocinæ

\section{Calopsocinæ}

Hind edge of head sharp; venation partly netted

Hind edge of head rounded; venation not netted

Calopsocini

Ptiloneurini

\section{Cæcilinæ}

1. Stigma veined, no cubital fork ……....... Neurostigmini Stigma not veined ............................................................................

2. No cubital fork ……...................................... Peripsocini Cubital fork present …….......................................................

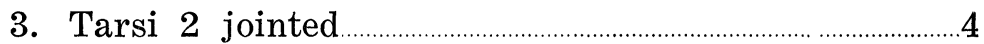
Tarsi 3 jointed, head broad at eyes...................esopsocini

4. Hind edge of head rounded .................................. Cæcilini Hind edge of head sharp ............................................ Dypsocini

\section{Psocinæ}

1. A cross-vein between stigma and radius.....Stenopsocini No such cross-vein

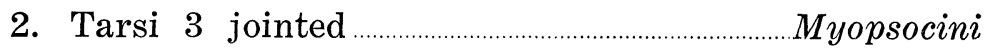
Tarsi 2 jointed. Psocini

Thyrsophorinæ

The few genera here do not require tribes. 

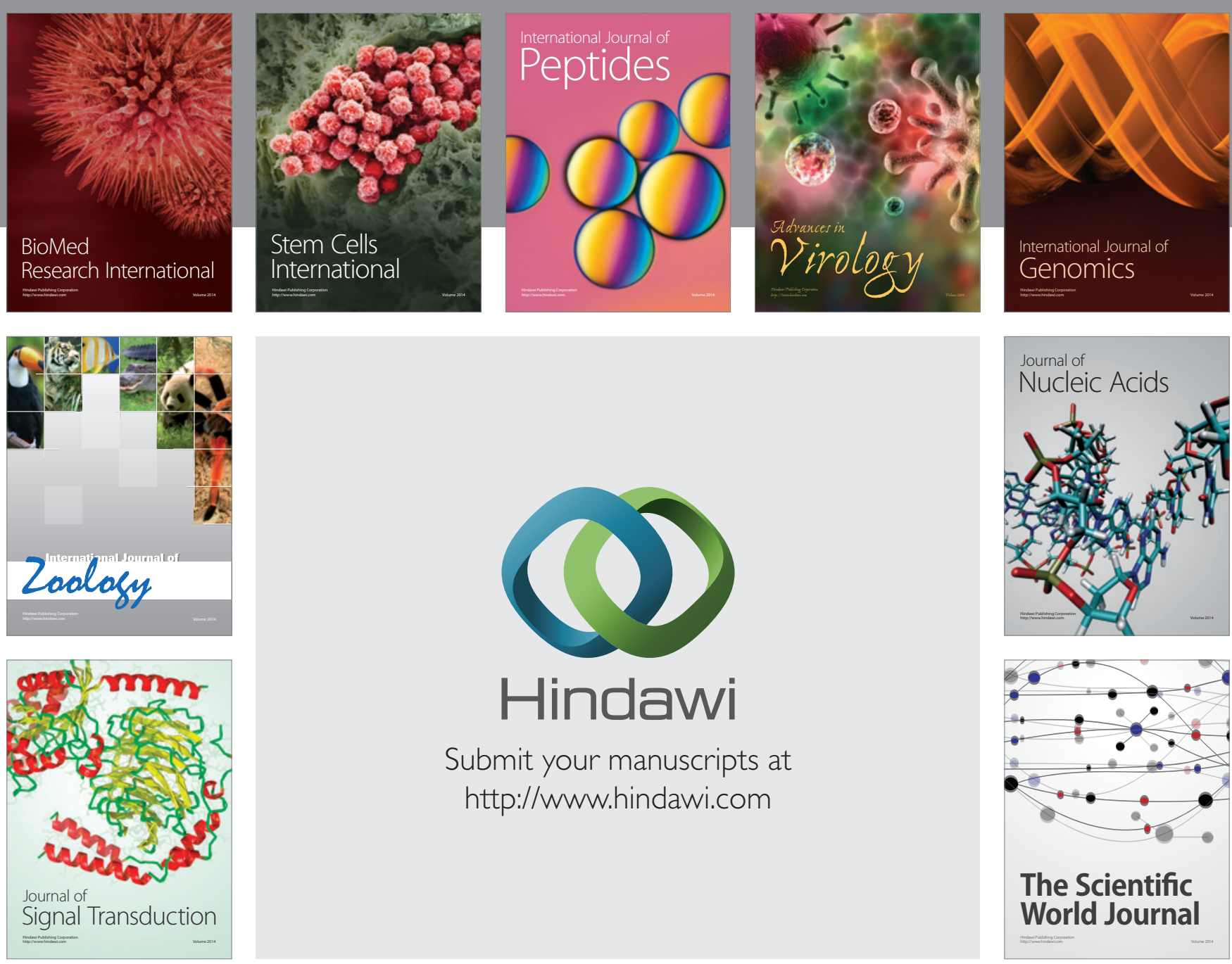

Submit your manuscripts at

http://www.hindawi.com
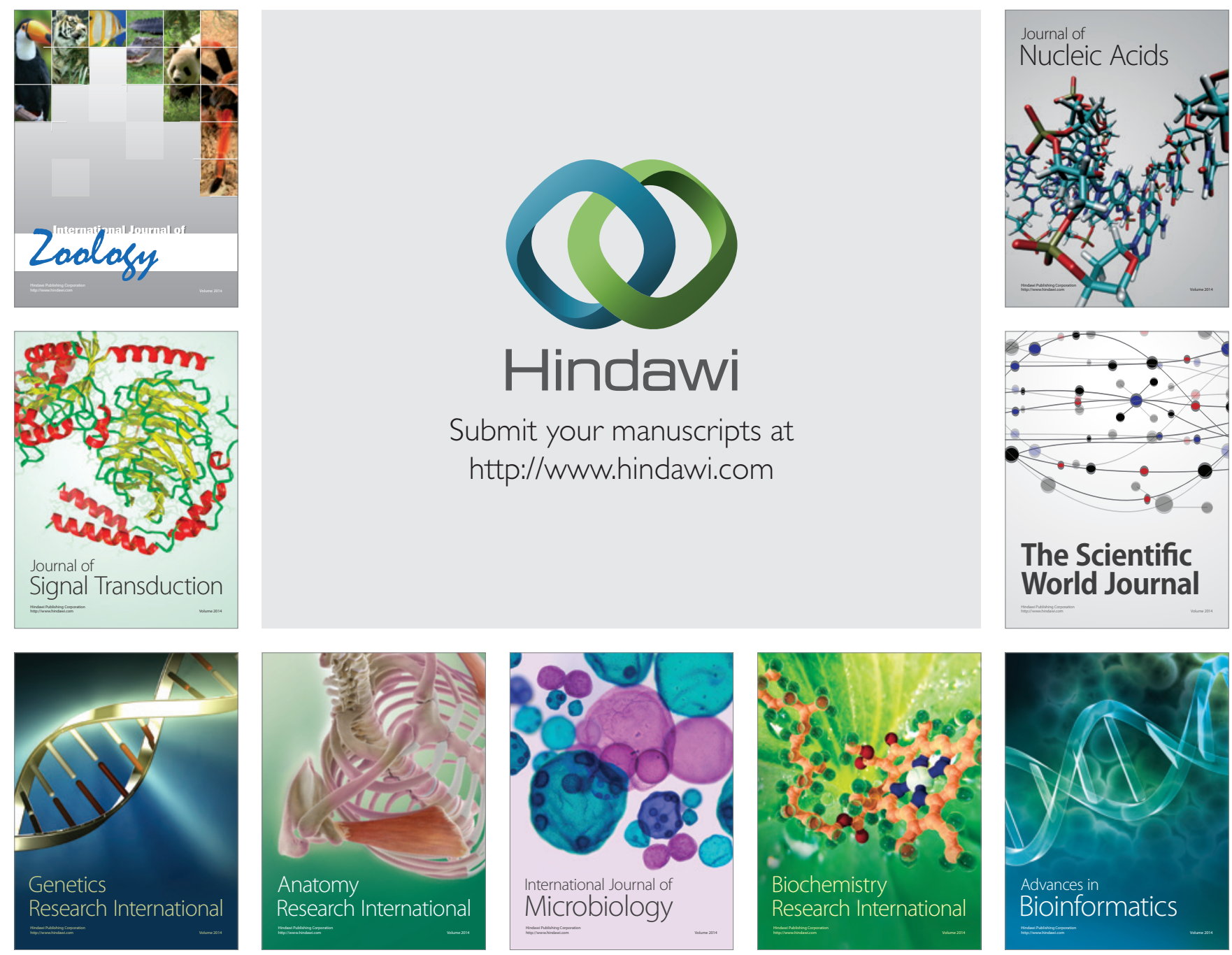

The Scientific World Journal
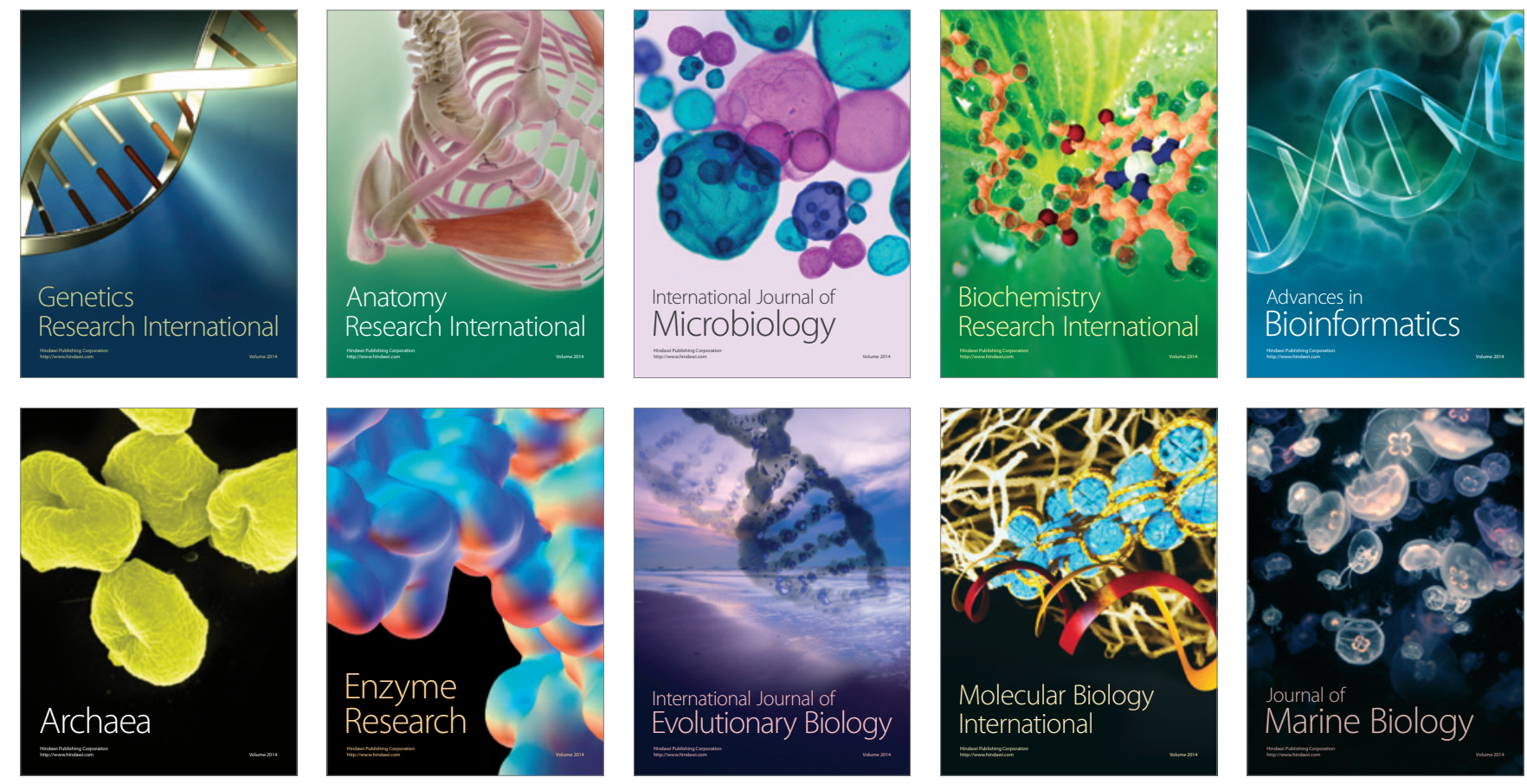